\title{
Molecular characterization of organic matter mobilized from Bangladeshi aquifer sediment: tracking carbon compositional change during micro- bial utilization
}

Lara E. Pracht et al.

Correspondence to: Rebecca B. Neumann (rbneum@uw.edu)

The copyright of individual parts of the supplement might differ from the CC BY 4.0 License. 


\section{Section S1: Calculation of organic carbon in sediment}

Sediment Porewater Organic Carbon $(\mathrm{DOC})=0.33 \pm 0.06 \mathrm{mg}$ OC g-1 sediment

Sediment Organic Matter $(\mathrm{LOI})=6.5 \pm 1.5 \mathrm{mg} / \mathrm{g}$

Using van Bemmelan factor (Burt, 2011) $(58 \% \mathrm{OM}=\mathrm{OC})$ to estimate sediment OC:

$6.5 \mathrm{mg} / \mathrm{g} * 0.58=3.77 \mathrm{mg} \mathrm{OC} / \mathrm{g}$ sed

DOC in sediment porewater as percent of sediment OC:

$$
0.33 / 3.77 * 100=8.75 \%
$$

Error for the above calculation:

$$
\begin{aligned}
& \text { Err,gy }=0.06 / 3.77=0.0159 \\
& \begin{aligned}
& \text { Err,gt }= 0.33 /\left(3.77^{\wedge} 2\right)^{*}\left(0.58^{*} 1.5\right)=0.0202 \\
& \text { Err } \quad=\operatorname{sqrt}\left[(0.06 / 3.77)^{\wedge} 2+\left(0.33 /\left(3.77^{\wedge} 2\right)^{*}\left(0.58^{*} 1.5\right)\right)^{\wedge} 2\right] \\
& \quad=0.0257 \mathrm{mg} \mathrm{OC} / \mathrm{g} \text { sed }
\end{aligned} \\
& \begin{aligned}
0.0257 / 3.77^{*} 100=0.68 \%
\end{aligned}
\end{aligned}
$$

DOC in sediment porewater represented $8.8 \pm 0.7 \%$ of OC in sediment. 
Table S1. Dissolved organic carbon concentrations in initial waters $\left(\mathbf{m g - C ~} \mathbf{L}^{-1}\right) *$

\begin{tabular}{|l|l|l|l|}
\hline Initial Waters & Pond Recharge & Rice Field Recharge & Sediment Porewater \\
\hline Rep 1 & 27.0 & 12.3 & 856 \\
\hline Rep 2 & 29.0 & 25.3 & 1103 \\
\hline Rep 3 & 33.1 & & 1219 \\
\hline
\end{tabular}

* Samples combined together during processing of FT-ICR-MS data are grouped together with thick lines.

Table S2. Dissolved organic carbon concentrations in incubation waters $\left(\mathrm{mg}-\mathrm{C} \mathrm{L}^{-1}\right)^{*}$

\begin{tabular}{|c|c|c|c|c|c|c|c|c|c|c|}
\hline & & $\begin{array}{c}1.5 \\
\text { days }\end{array}$ & $\begin{array}{c}17 \\
\text { days }\end{array}$ & $\begin{array}{c}18 \\
\text { days }\end{array}$ & $\begin{array}{c}19 \\
\text { days }\end{array}$ & $\begin{array}{c}20 \\
\text { days }\end{array}$ & $\begin{array}{c}80 \\
\text { days }\end{array}$ & $\begin{array}{c}81 \\
\text { days }\end{array}$ & $\begin{array}{c}91 \\
\text { days }\end{array}$ & $\begin{array}{c}184 \\
\text { days }\end{array}$ \\
\hline \multirow{3}{*}{$\begin{array}{c}\text { Pond } \\
\text { Recharge, } \\
\text { Sterilized } \\
\text { Sediment }\end{array}$} & Rep 1 & 212.9 & 219.30 & & 254.6 & & & 253.4 & 184.7 & 222.9 \\
\hline & Rep 2 & 202.7 & 230.68 & & 238.4 & & & 240.5 & & \\
\hline & $\begin{array}{c}\text { Avg. } \\
\text { (stdev) }\end{array}$ & $\begin{array}{c}207.8 \\
(7.2)\end{array}$ & \multicolumn{4}{|c|}{$235.8(14.8)$} & \multicolumn{3}{|c|}{$226.2(36.5)$} & \\
\hline \multirow{3}{*}{$\begin{array}{c}\text { Rice } \\
\text { Recharge, } \\
\text { Sterilized } \\
\text { Sediment }\end{array}$} & Rep 1 & 226.0 & 213.48 & & & 264.9 & & 230.7 & 201.8 & 247.4 \\
\hline & Rep 2 & 369.3 & 220.73 & & & 216.0 & & 245.5 & & \\
\hline & $\begin{array}{c}\text { Avg. } \\
\text { (stdev) }\end{array}$ & $\begin{array}{c}297.7 \\
(101.4)\end{array}$ & \multicolumn{4}{|c|}{$228.8(24.3)$} & \multicolumn{3}{|c|}{$226.0(22.2)$} & \\
\hline \multirow{3}{*}{$\begin{array}{c}\text { Pond } \\
\text { Recharge, } \\
\text { Native } \\
\text { Sediment }\end{array}$} & Rep 1 & 145.0 & & 162.9 & 153.8 & & 50.9 & & 40.0 & \\
\hline & $\operatorname{Rep} 2$ & 147.0 & & 161.6 & 155.6 & & & & & \\
\hline & $\begin{array}{c}\text { Avg. } \\
\text { (stdev) }\end{array}$ & $\begin{array}{l}146.0 \\
(1.4)\end{array}$ & \multicolumn{4}{|c|}{$158.5(4.5)$} & \multicolumn{3}{|c|}{$45.5(7.7)$} & \\
\hline \multirow{3}{*}{$\begin{array}{c}\text { Rice } \\
\text { Recharge, } \\
\text { Native } \\
\text { Sediment }\end{array}$} & Rep 1 & 135.5 & & 145.0 & & 148.6 & 37.3 & & 26.67 & 20.75 \\
\hline & Rep 2 & 142.6 & & 174.2 & & 140.8 & 31.5 & & & \\
\hline & $\begin{array}{c}\text { Avg. } \\
\text { (stdev) }\end{array}$ & $\begin{array}{l}139.1 \\
(5.0)\end{array}$ & \multicolumn{4}{|c|}{$152.1(15.1)$} & \multicolumn{3}{|c|}{$31.77(5.3)$} & \\
\hline
\end{tabular}

* Samples combined together during processing of FT-ICR-MS data are grouped together with thick lines.

Table S3. Methane concentrations in incubation bottles $\left(\mathrm{mg}-\mathrm{C} \mathrm{L}^{-1}\right)$

\begin{tabular}{|l|l|l|}
\hline & 18 days & 273 days \\
\hline Pond Recharge, Sterilized Sediment & Below detection & Below detection \\
\hline Rice Recharge, Sterilized Sediment & Below detection & Below detection \\
\hline Pond Recharge, Native Sediment & Below detection & $198 \pm 46$ \\
\hline Rice Recharge, Native Sediment & Below detection & $368 \pm 45$ \\
\hline
\end{tabular}


Table S4. Compound Class Assignment

\begin{tabular}{|l|c|c|}
\hline Compound Class & H-to-C ratio range & O-to-C ratio range \\
\hline Lipid-like & $1.5-2.3$ & $0-0.2$ \\
\hline Protein-like & $1.5-2.2$ & $0.2-0.5$ \\
\hline Amino sugar-like & $1.5-2.2$ & $0.5-0.7$ \\
\hline Carbohydrate-like & $1.5-2.3$ & $0.7-1.1$ \\
\hline Lignin-like & $0.8-1.5$ & $0.25-0.67$ \\
\hline Tannin-like & $0.6-1.2$ & $0.67-0.95$ \\
\hline \multirow{2}{*}{ Condensed hydrocarbon-like } & $0.8-1.2$ & $0-0.25$ \\
& $0-0.8$ & $0-0.5$ \\
\hline
\end{tabular}

- Based on D'Andrilli et al. (2015).

- Compounds falling outside of designated ratios ranges were classified as 'other' 
Figure S1
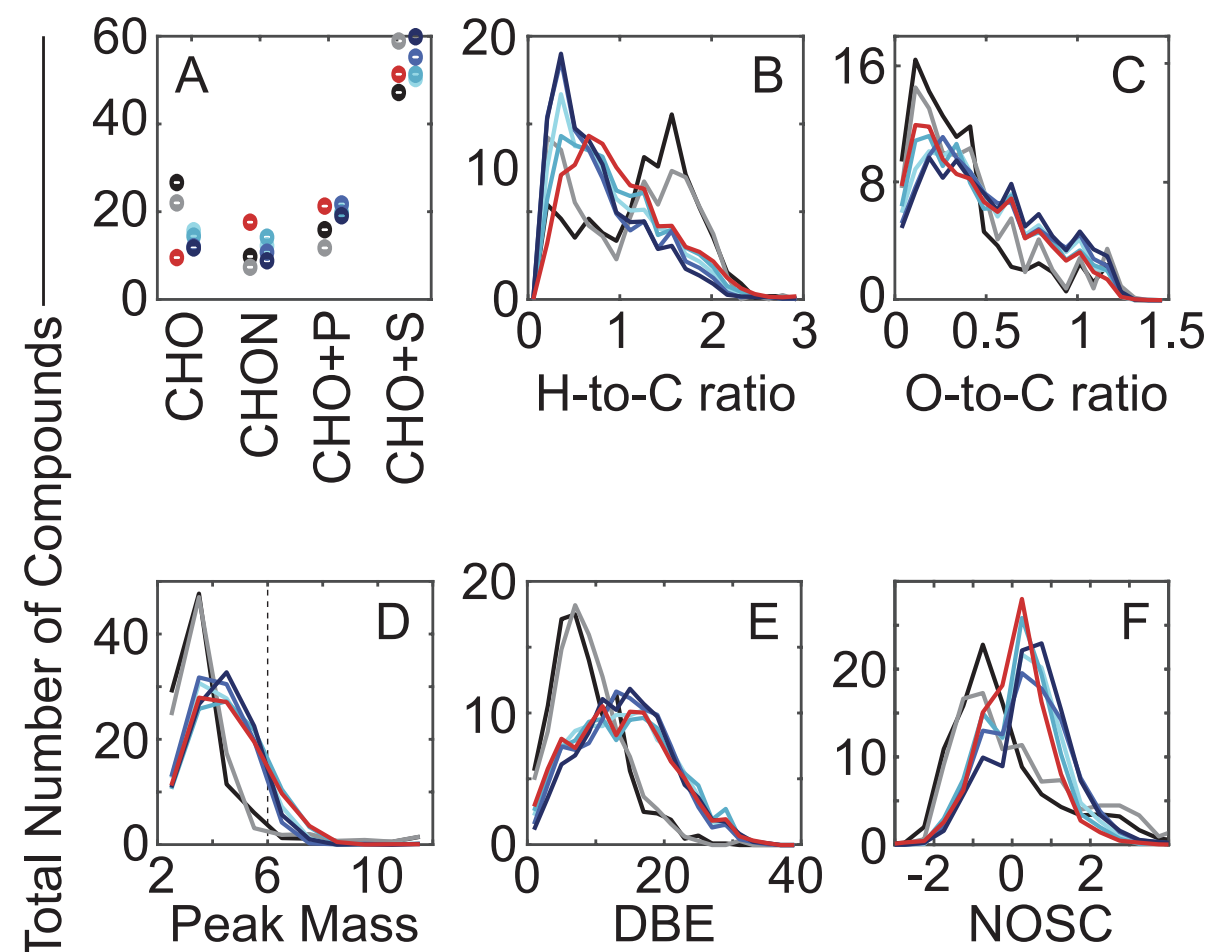

H-to-C ratio

O-to-C ratio
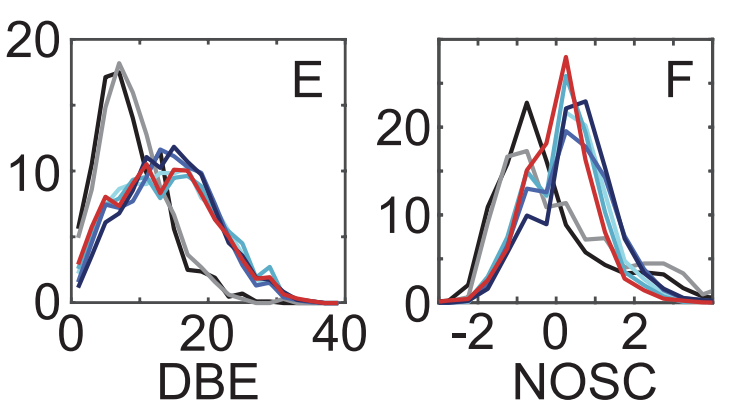

웅
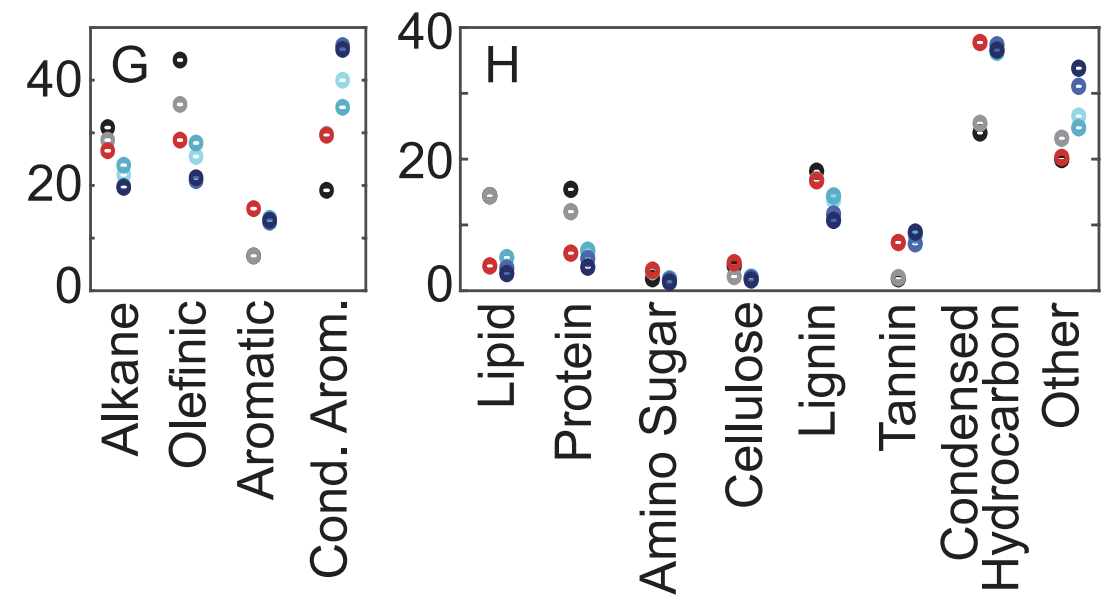

-Pond Rechrg. - Rice Rechrg. - Sediment PW

Pond Incubation, Day 1: - Abiotic —Biotic

Rice Incubation, Day 1: -Abiotic -Biotic

Chemical characteristics of mobilized SOC (red), DOC in pond recharge water (black), DOC in rice field recharge water (grey), and DOC in day-1 incubation waters (blues). (a) Percent of identified compounds in heteroatom groups. Proportional distributions of (b) H-to-C ratios, (c) O-to-C ratios, (d) peak mass, (e) double bond equivalents, and (f) nominal oxidation states of carbon. Percent of identified compounds in groupings based on (g) $\mathrm{AI}$ (alkanes, $\mathrm{AI}=0$; olefinics, $0<\mathrm{AI} \leq 0.5$; aromatics, $\mathrm{AI}>0.5$; condensed aromatics, $\mathrm{AI} \geq 0.67$ ) and (h) compound classifications (Table $\mathrm{S} 4$ ). 
Figure S2

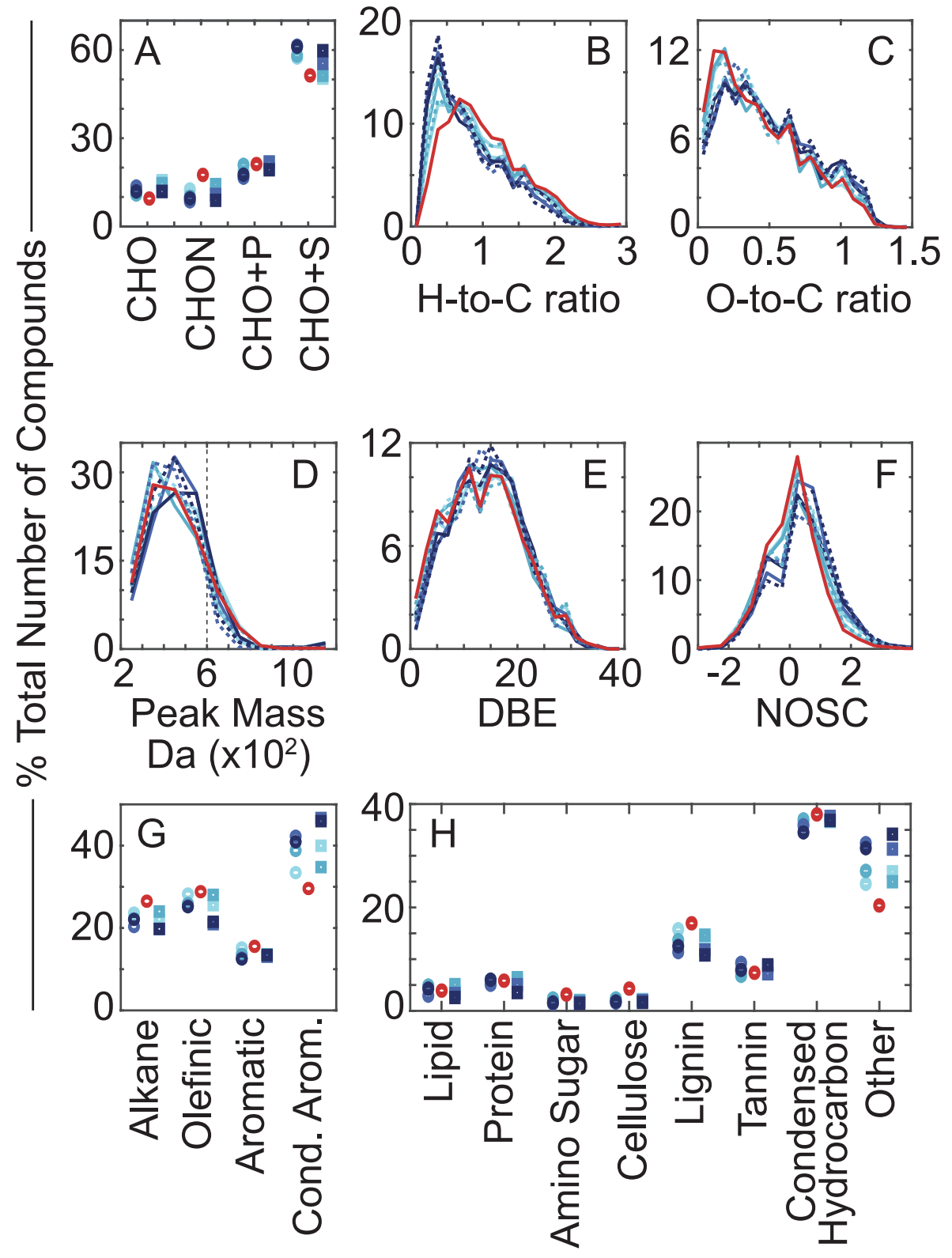

\begin{tabular}{|c|}
\hline - Sediment Porewater \\
\hline 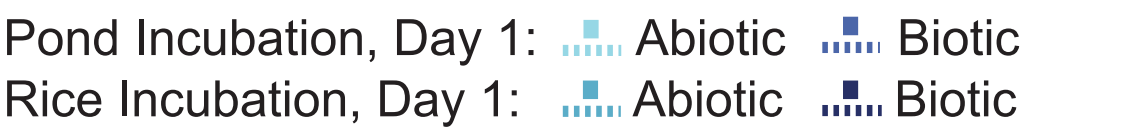 \\
\hline $\begin{array}{l}\text { Newly Detected Compounds on Day } 18 \text { vs. Day 1: } \\
\text { Pond Incubation: } \_ \text {Abiotic } \_ \text {Biotic } \\
\text { Rice Incubation: } \_ \text {Abiotic } \_ \text {Biotic }\end{array}$ \\
\hline
\end{tabular}

Chemical characteristics of mobilized SOC (red), DOC in incubation waters from day 1 (dashed blues, squares), and newly detected compounds on incubation day 18 that were not detected on incubation day 1 (solid blues, circles). Panels as identified in Figure S1. 


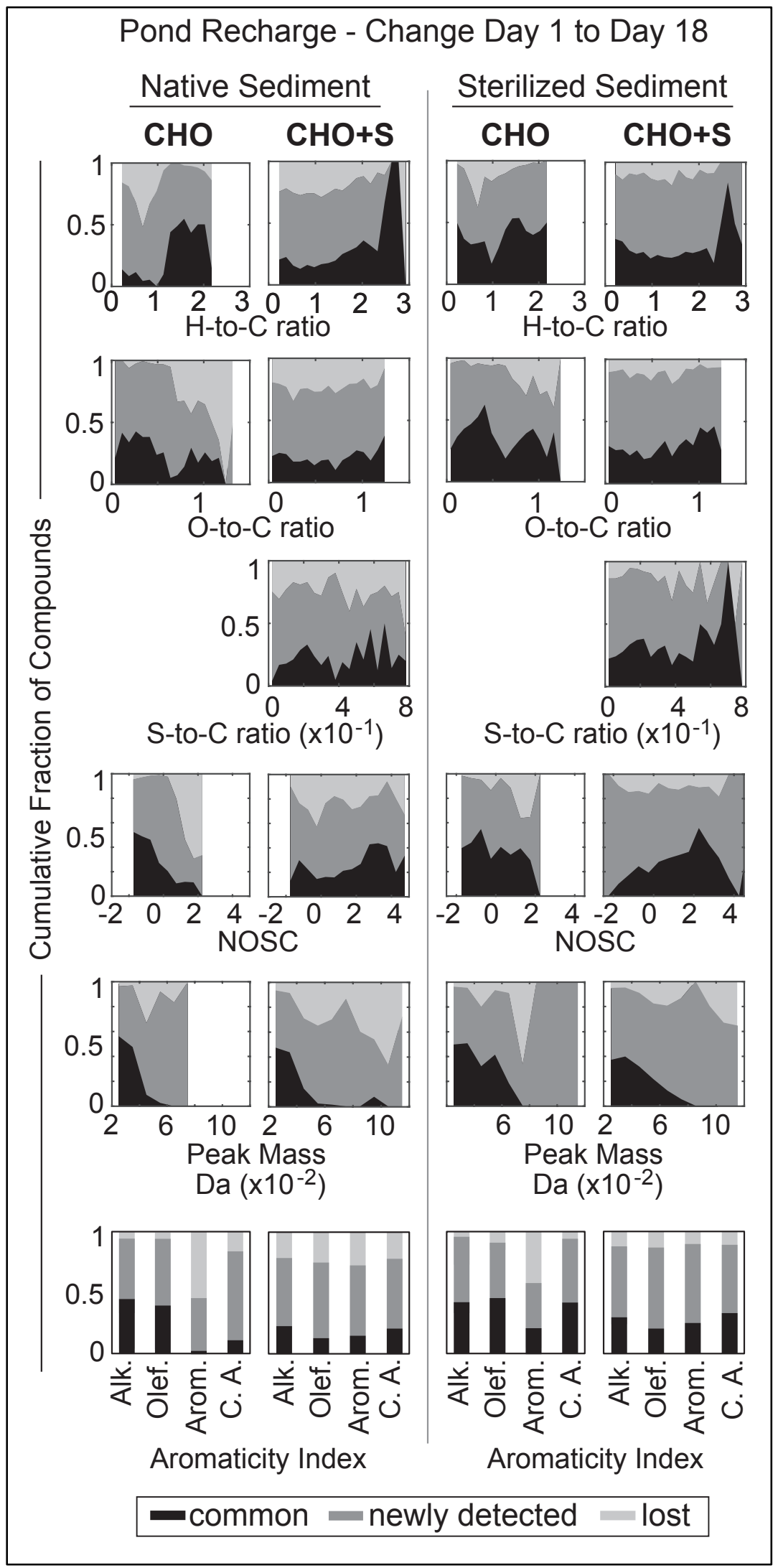

Relative change in chemical indices between day 1 and day 18 for pond recharge water incubated with native sediment and sterilized sediment. Plotted are the cumulative fractions of compounds that were identified at both time points, i.e., common (black), identified at the second time point but not at the first, i.e., newly detected (dark grey), and identified at the first time point but not at the second, i.e., lost (light grey). Compounds were separated by heteroatom group $(\mathrm{CHO}$ and $\mathrm{CHO}+\mathrm{S}$ groups are shown) and characterized based on $\mathrm{H}$-to-C ratio, O-to-C ratio, $\mathrm{S}$ to- $\mathrm{C}$ ratio, nominal oxidation state of carbon (NOSC), peak mass, and aromaticity index. 
Figure S4

Peak Mass - Change from Day 1 to Day 18
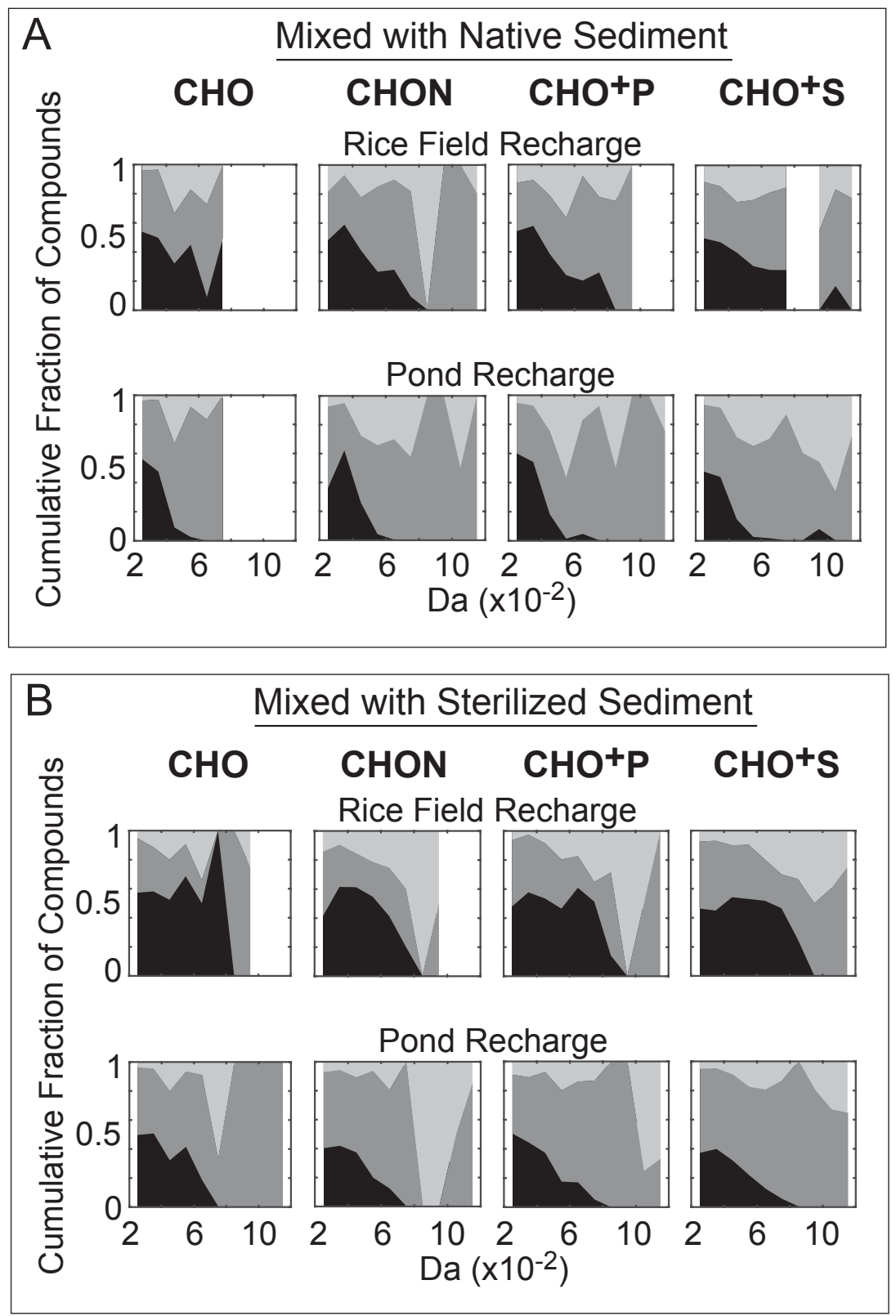

common newly detected lost

Relative change in peak mass between day 1 and day 18 for both rice field recharge water (top row) and pond recharge water (bottom row) incubated with (a) native sediment and (b) sterilized sediment. Plotted are the cumulative fractions of compounds that were identified at both time points, i.e., common (black), identified at the second time point but not at the first, i.e., newly detected (dark grey), and identified at the first time point but not at the second, i.e., lost (light grey). Compounds were separated by heteroatom group (CHO, $\mathrm{CHON}, \mathrm{CHO}+\mathrm{P}, \mathrm{CHO}+\mathrm{S})$. 


\section{Figure S5}

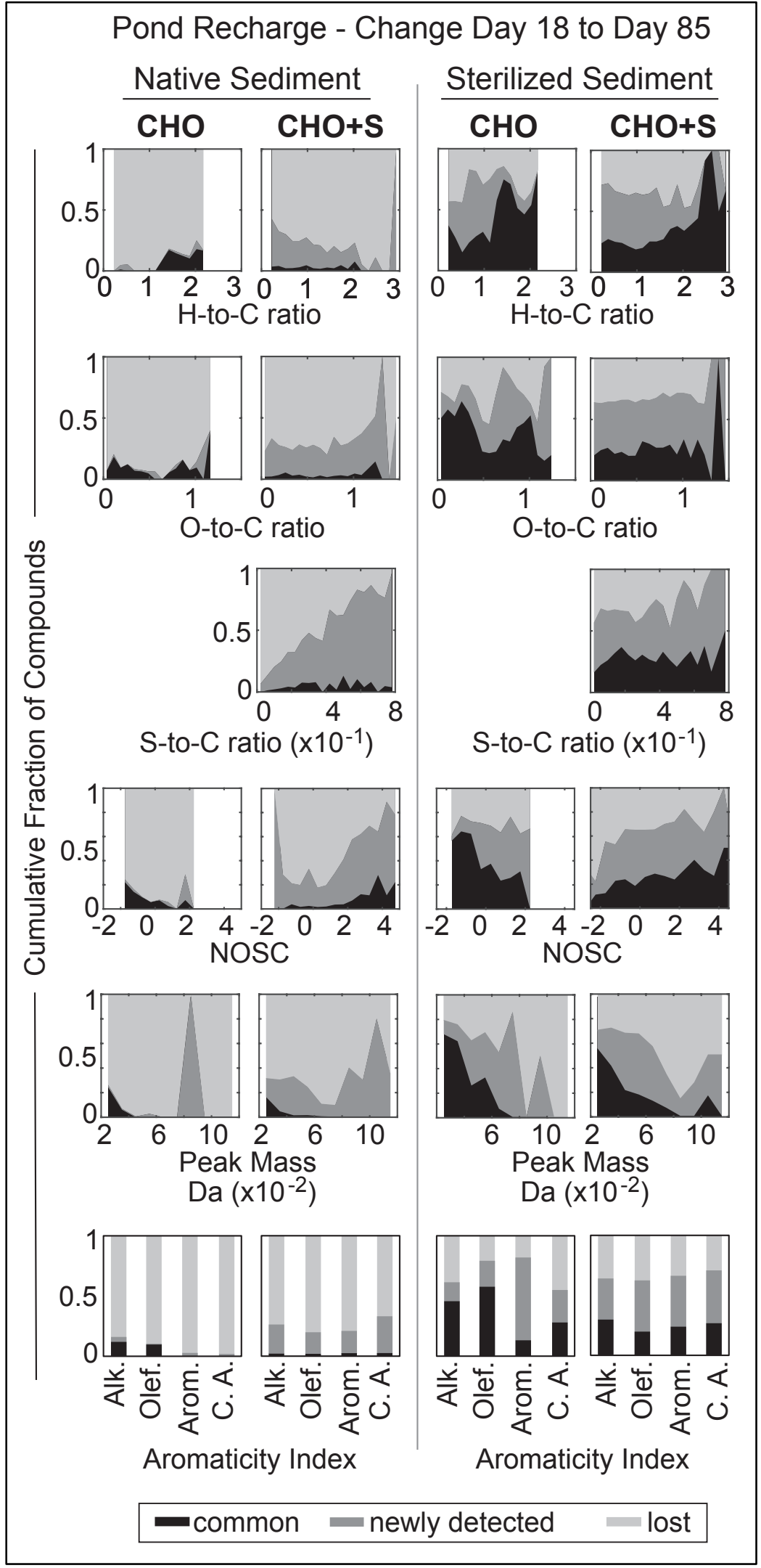

Relative change in chemical indices between day 18 and day 85 for pond recharge water incubated with native sediment and sterilized sediment. Plotted are the cumulative fractions of compounds that were identified at both time points, i.e., common (black), identified at the second time point but not at the first, i.e., newly detected (dark grey), and identified at the first time point but not at the second, i.e., lost (light grey). Compounds were separated by heteroatom group ( $\mathrm{CHO}$ and $\mathrm{CHO}+\mathrm{S}$ groups are shown) and characterized based on $\mathrm{H}$-to-C ratio, $\mathrm{O}-$ to- $\mathrm{C}$ ratio, $\mathrm{S}$-to- $\mathrm{C}$ ratio, nominal oxidation state of carbon (NOSC), peak mass, and aromaticity index. 
Figure S6
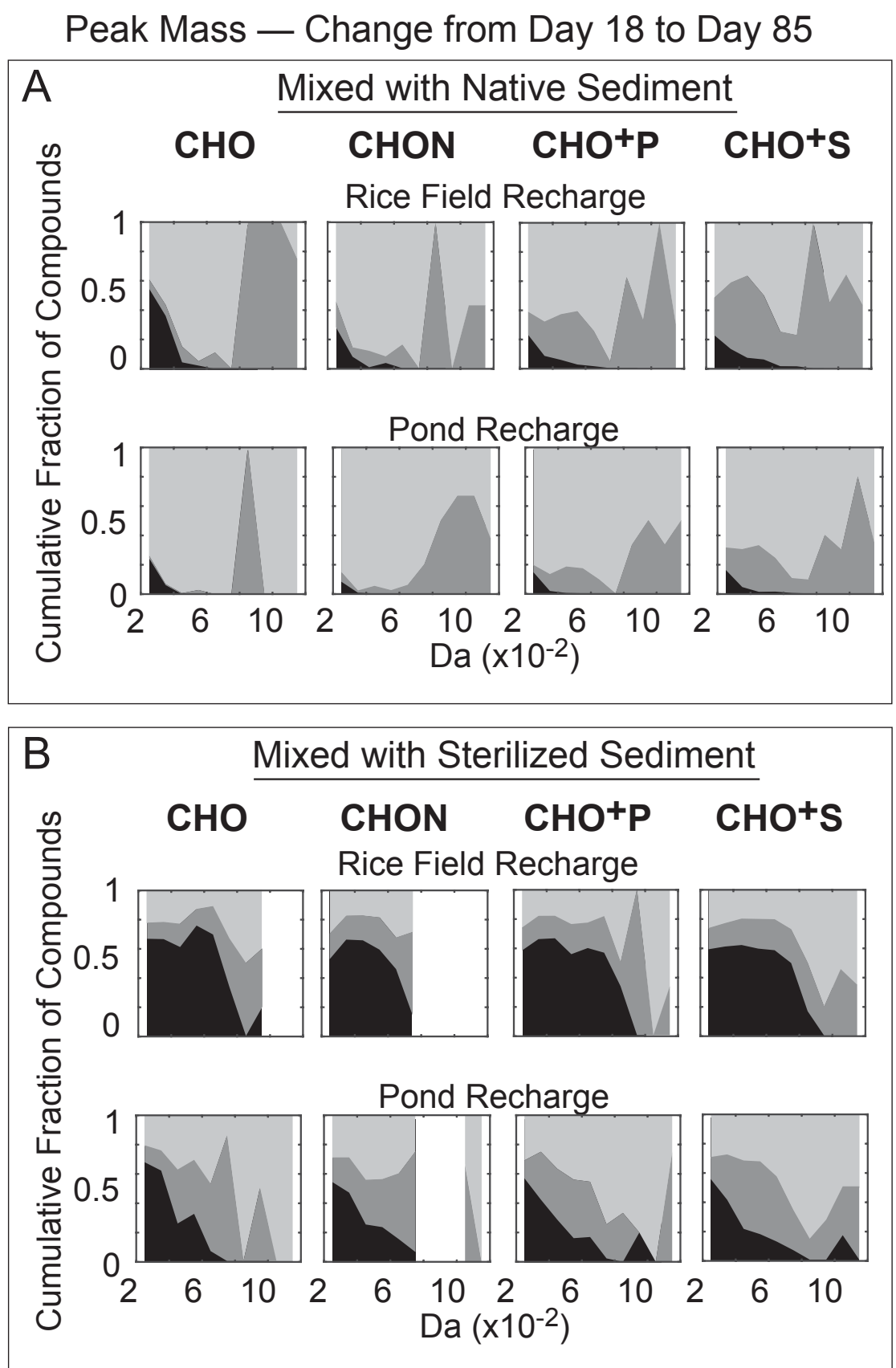

common newly detected lost

Relative change in peak mass between day 18 and day 85 for both rice field recharge water (top row) and pond recharge water (bottom row) incubated with (a) native sediment and (b) sterilized sediment. Plotted are the cumulative fractions of compounds that were identified at both time points, i.e., common (black), identified at the second time point but not at the first, i.e., newly detected (dark grey), and identified at the first time point but not at the second, i.e., lost (light grey). Compounds were separated by heteroatom group (CHO, $\mathrm{CHON}, \mathrm{CHO}+\mathrm{P}, \mathrm{CHO}+\mathrm{S})$. 


\section{REFERENCES}

Burt, R., Series Ed. Soil Survey Laboratory Information Manual; Soil Survey Investigations; 45, Version 2.0; United States Department of Agriculture, Natural Resources Conservation Service: National Soil Survey Center, Lincoln, Nebraska, 2011.

D'Andrilli, J., Cooper, W. T., Foreman, C. M. and Marshall, A. G.: An ultrahigh-resolution mass spectrometry index to estimate natural organic matter lability, Rapid Commun. Mass Spectrom., 29(24), 2385-2401, doi:10.1002/rcm.7400, 2015. 